\title{
Refuge
}

Canada's Journal on Refugees

Revue canadienne sur les réfugiés

\section{Forced Migration: Current Issues and Debates by Alice Bloch and Giorgia Doná (Eds.)}

\section{Anita H. Fábos}

Volume 35, Number 2, 2019

Private Sponsorship in Canada

URI: https://id.erudit.org/iderudit/1064828ar

DOI: https://doi.org/10.7202/1064828ar

See table of contents

Publisher(s)

Centre for Refugee Studies, York University

ISSN

0229-5113 (print)

1920-7336 (digital)

Explore this journal

Cite this review

Fábos, A. (2019). Review of [Forced Migration: Current Issues and Debates by Alice Bloch and Giorgia Doná (Eds.)]. Refuge, 35(2), 129-129.

https://doi.org/10.7202/1064828ar 


\title{
Forced Migration: Current Issues and Debates
}

\author{
n \\ Edited by Alice Bloch and Giorgia Donà \\ Abingdon-on-Thames, uk: Routledge, 2018, 178 pp.
}

W ith contributions by key thinkers in the field, Alice Bloch and Giorgia Donás slim edited volume tackles some of the most profound shifts in the global context of forced migration today. The book combines a frank assessment of how unsuitable the current legal and humanitarian frameworks are today, with empirical evidence of people's struggles for rights, resources, and belonging in a changing landscape of displacement. Although the editors deliberately avoid offering "solutions" to address the twenty-first-century realities presented here, the questions raised throughout require readers to rethink our reliance on current paradigms that frame the field of practice. Authors give readers the benefit of not only their long experience tussling with the conceptual minefields of terminology and the historical boundaries of the field, but also helpful guidance for where to go next.

Bloch and Doná identify the major challenges, debates, and knowledge gaps in forced migration studies, and organize them along three themes in the introductory chapter: (1) the reconfiguration of borders, (2) the expansion of prolonged exile, and (3) changes in protection and rights. The chapters that follow are divided into two sets, with the first four (Zetter, Banerjee and Sammadar, Voutira, and Hyndman and Giles) providing a theoretical overview that loosely maps onto the book's themes. Zetter sets out a strong analysis of why the field still has not yet settled on a common understanding of what or who comprises our subject matter. His chapter goes well beyond describing tensions between normative concepts such as refugee and descriptive but ambiguous concepts like forced displacement to call for a realignment of our conceptualization itself with the drivers and processes of forced migration. His evaluation points away from the contemporary reconfiguration of borders towards a global order structured by displacements (through armed conflicts, environmental degradation, development projects, and natural disasters) that must be reconceptualized accordingly. Banerjee and Sammadar write more explicitly on bordering and the failure of forced migration studies to include the vast displacements produced by colonial systems and post-colonial disruptions. Their call to widen the scope of the field geographically and historically is taken up by Voutira, who has long modelled these recommendations through her pioneering scholarship on
post-Second World War re-bordering and displacements that asked us to review historical patterns of state and ethnic formations while unpacking the dilemmas of rights and identities. Voutira's chapter again reminds us that we define large-scale forced displacements as unconnected "crises" at the risk of forgetting what we have learned about the participation of displaced people in societies in which we all live. Hyndman and Giles round out this accomplished group of theoreticians with a sharp analysis of how and why "palliative" humanitarianism must be replaced with practices that remove the us/them divide that supports "protracted refugee situations." They do this through an artful combination of robust policy analysis and grounded theory from their work with Dadaab-based research participants. This chapter is the best argument yet for why forced migration studies needs to move beyond the paradigm of "durable solutions" to call states out on this unattainable policy goal.

The second set of chapters (Majidi and Schuster; Landau, Doná and Godin; and Chimienti, Counilh, and Ossipow) present equally sharp critiques of current policies that shape access to rights for people forcibly displaced, together with their lived experiences and ongoing formation of identities. Majidi and Schuster's contribution on deportation and forced return is a well-crafted rebuke of the wishful thinking behind lingering support for durable solutions. This brief unpacking of this "inhumane and illiberal practice" takes into account the history, practice, impact, and business of deportation. But, following upon the previous chapter, it shines an uncomfortable light on the idea of "permission to remain" within state boundaries, and all that implies. Next in this set is Landau's beautifully holistic rumination on the transformation of cities and current interactions among urban forced migrants and other residents, humanitarians, and municipal policy-makers. Landau and his colleagues have tracked experiments that provide services to refugees and other urbanites without legal protection, recognizing the agency of forced migrants themselves in strategizing their own livelihoods while working with local authorities to build solidarity around pro-refugee micro-interventions.

The last two contributions also draw on their authors' empirical work among people remaking lives and identities in contemporary displacement. Doná and Godin demonstrate the short- and long-term uses of mobile technologies 
for people on the move and the diaspora-identified who strive to maintain belonging while separated geographically from other community members. The authors also cover the use of technology for activism and humanitarianism, as well as its flip side, surveillance. Their grounded analysis of mobile technology and all its uses at the securitized border at Calais, France, points to the emergence of mobile-centred economies and infrastructures, and how they relate to power differentials. The last empirical contribution discusses current experiences and discourses of children from three ethno-national communities who came to Switzerland as refugees. Chimienti, Counilh, and Ossipow find that their complex emotions about the countries of their parents' birth have emerged through transnational engagement such as money transfers, home visits, and activism. Their feelings of belonging to Switzerland, meanwhile, strengthen even while their heritage identities transform as a result of these activities. This chapter side-steps the usual either/or discourse around nation-based identities and contributes to our understanding of the complexities of displacement in the contemporary era.

The volume concludes with Bloch and Donás brief summary of the questions raised by the contributing authors, and some suggestions for moving forward through a rethinking of tired narratives and discourses of the post-colonial world order. Zetter's aggregation of estimates of refugees, asylum seekers, internally displaced people, UNRWA-registered Palestinians, disaster-displaced people, and developmentdisplaced people (but not including those displaced by landgrabs) proposes that at least 99.6 million people today are living with displacement. Bloch and Donás scholarly contribution illuminates the signposts towards a person-centred framework that puts into practice an alternative vision to the unworkable "people out of place" approach. The collection is underserved by the rather poor quality of Routledge's production; while books today may be required to economize through tiny text and inferior paper, the binding of my copy has already failed to hold the book's pages together. A final plea to all of us working in the academic world of forced migration studies: let us try harder to translate our crucially important ideas into formats and writing styles that are clear to non-scholars. Some authors in this collection manage this better than others, and a suggestion for all editors is to bring all contributions up to the same level of cogent writing.

Anita H. Fábos is professor, Department of International Development, Community \& Environment, Clark University. She can be contacted at AFabos@clarku.edu. 